\title{
BEST PRACTICE PENGARUH PENGGUNAAN APLIKASI GOOGLE CLASSROOM TERHADAP KUALITAS PEMBELAJARAN DAN HASIL BELAJAR SISWA PADA MATA PELAJARAN SENI MUSIK KELAS X DI SMAN 1 CANDIROTO
}

\author{
ACHMAD SOLICHUL HADI \\ SMA Negeri Candiroto Temanggung Jawa Tengah \\ Email : cicovendra@gmail.com
}

\begin{abstract}
ABSTRAK
Tujuan penelitian ini adalah (1) menjelaskan pengaruh penggunaan google classroom terhadap kualitas pembelajaran siswa pada mata pelajaran seni musik kelas X di SMAN 1 Candiroto. (2) menjelaskan pengaruh penggunaan google classroom terhadap hasil belajar siswa pada mata pelajaran seni musik kelas X di SMAN 1 Candiroto. Penelitian ini menggunakan metode kuantitatif. Populasi dalam penelitian ini adalah siswa kelas X SMAN 1 Candiroto. Sampel penelitian ditentukan dengan menggunakan teknik pumosive sampling yaitu siswa kelas X 3 SMAN 1 Candiroto. Teknik pengumpulan data menggunakan angket, tes objektif, observasi, wawancara dan dokumentasi. Hasil penelitian yang telah dilakukan menyatakan bahwa: (1) terdapat pengaruh positif signifikan penggunaan google classroom, terhadap kualitas pembelajaran siswa pada mata pelajaran seni musik kelas X di SMAN 1 Candiroto dengan nilai t hitung $>\mathrm{t}$ tabel $(2.357>2.045)$ dan nilai signifikansi 0.025 . Artinya penggunaan google classroom dapat meningkatkan kualitas pembelajaran siswa pada mata pelajaran seni musik kelas X di SMAN 1 Candiroto. (2) terdapat pengaruh positif signifikan penggunaan google classroom terhadap hasil belajar siswa pada mata pelajaran seni musik kelas X di S M A N 1 Candiroto sebesar 2.44 kali dengan signifikansi 0.016. Artinya penggunaan google classroom berpengaruh signifikan sebesar 2.44 kali terhadap hasil belajar siswa.
\end{abstract}

Kata Kunci: Google classroom, Kualitas Pembelajaran, Hasil belajar.

\section{PENDAHULUAN}

Classroom sebagai salah satu jenis dari sekian banyak jenis learning management sytem banyak dipilih sekolah sebagai media pembelajaran dalam masa pandemi ini. Classroom memiliki berbagai keunggulan yang dapat menunjang proses berlangsungnya pembelajaran jarak jauh. Keutamaan classroom seperti related dengan perkembangan teknologi, praktis dan mudah diakses, proses pembelajaran menjadi lebih efisien, melatih kemandirian bagi murid, terdapat fitur-fitur tambahan yang mempermudah penugasan atau penyimpanan dokumen, tidak terkendala jarak, dan menjadi media yang sangat praktis dalam bertukar pikiran atau menjadi wadah diskusi. Di SMA Negeri 1 Candiroto nyata sekali perbedaan efektifitas penggunaan classroom dengan media sebelumnya seperti penggunaan grup wa dan juga telegram. Dengan classroom permasalahan yang timbul dalam pembelajaran daring seperti keaktifan siswa, diskusi yang kurang interaktif dan juga pengerjaan tugas yang tertunda menjadi sangat berkurang. Jika sebelumnya guru menggunakan vidio call, voice note dengan banyak siswa dengan pemanfaatan google meet pada fitur classroom mempermudah guru untuk berinteraksi dengan siswa, melihat keaktifan siswa dan juga melakukan absensi langsung.tua, masyarakat, dan guru sangat berperan penting dalam membangkitkan minat dan motivasi anak untuk belajar.

Lembaga pendidikan melakukan inovasi dalam proses pembelajaran. Salah satu bentuk inovasi tersebut ialah dengan melakukan pembelajaran secara online atau daring (dalam jaringan). Pembelajaran Daring bertujuan memberikan layanan pembelajaran bermutu dalam jaringan (daring) yang bersifat masif dan terbuka untuk menjangkau peminat yang lebih banyak dan lebih luas (Sofyana \& Rozaq, 2019).Walaupun dikatakan oleh ( Bilfaqih \& Qamruddin, 2015 ) pembelajaran daring mampu memberikan layanan yang menarik dan efekti ( f, tetap saja dalam pelaksanaanya memiliki tantangan sendiri. Harjanto dan Sumunar (2018) menyatakan bahwa pembelajaran daring ini merupakan proses transformasi pendidikan konvensional ke dalam bentuk digital sehingga memiliki tantangan dan peluang tersendiri. Oleh karena itu, 
adanya hambatan yang terdapat dalam proses pembelajaran daring harus dapat ditemukan solusinya.

Google classroom merupakan aplikasi berupa learning system management yang disediakan google dan bisa dihubungkan dengan email, sehingga mudah untuk diakses (Suhada dkk., 2020).Google classroom dianggap sebagai salah satu platform terbaik di luar sana untuk meningkatkan alur kerja dan termasuk layanan web gratis, yang dikembangkan oleh google untuk sekolah, yang bertujuan untuk menyederhanakan, membuat, mendistribusikan, dan menilai tugas dengan tanpa kertas (Santosa, Negara, and Samsul Bahri 2020).Dengan Google Classroom diharapkan menjadi solusi untuk mengatasi kesulitan dalam melaksanakan pembelajaran daring dan diharapkan dapat mempertahankan kelas tetap aktif meskipun sekolah telah ditutup walaupun pendidik dan peserta didik tidak dapat bertemu secara langsung namun proses pembelajaran dapat berjalan dengan lancar. Guru dan pendidik sebagai elemen penting dalam pengajaran diharuskan melakukan migrasi besar- besaran yang belum pernah terjadi sebelumya dari pendidikan tatap muka tradisional ke pendidikan online atau pendidikan jarak jauh (Bao, 2020; Basilaia \& Kvavadze, 2020).

Pembelajaran dengan menggunakan perkembangan teknologi yang ada saat ini, memberi kesempatan dan peluang bagi guru untuk dapat meningkatkan dan mengembangkan kompetensinya terutama kompetensi pedagogik dan profesional. Penggunaan teknologi dalam pembelajaran diasumsikan dan diharapkan dapat menjadi solusi dalam mengatasi permasalahan pembelajaran di kelas yang disebabkan oleh kurang optimalnya peran guru dalam memanfaatkan penggunaan teknologi dalam dunia pendidikan

Adapun aplikasi dari teknologi informasi dan komunikasi yang potensial untuk dimanfaatkan sebagai media pembelajaran ialah internet, sudah cukup banyak sekolah-sekolah yang memiliki komputer yang terkoneksi (link) ke internet. Perkembangan teknologi pembelajaran menggunakan media internet saat ini berkembang pesat sehingga memberikan kemudahan, kebebasan, dan keleluasaan dalam menggali ilmu pengetahuan secara online.

Berdasarkan hasil survei dari Asosiasi Penyelenggara Jaringan Internet Indonesia (APJII) pada data lnfogarfis Penetrasi dan Perilaku Pengguan Internet di Indonesia tahun 2017, diketahui bahwa pengguna internet di Indonesia sebanyak 143,26 juta jiwa. Dimana total penduduk Indonesia 262 juta jiwa, artinya sebanyak 54,68\% penduduk di Indonesia merupakan pengguna internet. Adapun dari hasil survey tersebut di peroleh data tentang pemanfaat internet di bidang edukasi. Dari data tersebut diketahui bahwa pemanfaatan internet dalam bidang edukasi terbagi menjadi lima bagian yaitu Sebanyak 55.30\% digunakan untuk membaca artikel, $49.87 \%$ digunakan untuk melihat video tutorial, $21.73 \%$ digunakan untuk berbagi artikel atau video edukasi dan $14.63 \%$ digunakan untuk kegiatan pendaftaran sekolah

Google Classroom sesungguhnya dirancang untuk mempermudah interaksi guru dan siswa dalam dunia maya. Aplikasi ini memberikan kesempatan kepada para guru untuk mengeksplorasi gagasan keilmuan yang dimilikinya kepada siswa. Inovasi yang diberikan oleh Google For Education tersebut bertujuan untuk membantu menciptakan pembelajaran yang aktif, efektif, efisien dan menyenangkan.

Berdasarkan hasil pengamatan yang telah dilakukan oleh peneliti menunjukan bahwa SMA NEGERI 1 Candiroto adalah sekolah negeri yang memiliki sarana dan prasarana yang mampu mendukung dan menunjang pembelajaran dengan menggunakan media berbasis teknologi yaitu aplikasi Google Classroom. Tersedianya proyektor sebagai media pembelajaran dan fasilitas Wifi yang dapat diakses oleh tenaga pendidik dan peserta didik selama berada di gedung sekolah. Namun fasilitas yang disediakan oleh sekolah tersebut masih kurang dimanfaatkan secara optimal untuk kegiatan belajar mengajar. Sehingga, penggunaan aplikasi Google Classroom untuk membantu kegiatan pembelajaran masih jarang diterapkan oleh guru di sekolah, padahal pengoperasiaan Google Classroom ini tergolong mudah. Hal ini terjadi karena masih kurangnya pengetahuan guru tentang cara penggunaan Google Classroom dalam kegiatan pembelajaran dan masih kurangnnya penggunaan media pembelajaran berbasis 
teknologi di sekolah, padahal telah tersediannya fasilitas Wifi di Sekolah sebagai penunjang pelaksanan pembelajaran berbasis digital.

Oleh karena itu peneliti memilih SMA Negeri 1 Candiroto sebagai objek penelitan untuk melihat pengaruh penggunaan aplikasi Google Classroom terhadap kualitas pembelajaran dan hasil belajar siswa dengan menggunakan Google Classroom diharapakan peserta didik dapat melakukan kegiatan belajar kapan saja dan dimana saja, sehingga peserta didik tidak hanya mampu mencapai KKM sebesar 7,8 saja, tetapi juga dapat mencapai standar kompetensi yang menunjukan kinerja yang baik dalam mata pelajaran seni music Penggunaan aplikasi Google Classroom dalam kegiatan pembelajaran di sekolah merupakan salah satu langkah awal untuk memberikan gambaran dan persiapan pada peserta didik dalam menggunakan teknologi informasi. Sebagaimana yang telah diketahui bahwa pemerintah menyelenggarakan kebijakan mengenai Computer Based Test (CBT) atau sering kita sebut dengan Ujian Nasional (UN) berbasis komputer atau online. Maka penggunaan aplikasi tersebut dapat dijadikan sebagai proses membiasakan peserta didik dalam menggunakan teknologi informasi dan komunikasi yang semakin canggih. Selain itu, berbagai macam kegiatan yang ada di masyarakat pun seperti e-ktp, e-system perpajakan, transaksi jual beli, dan lain sebagainya kebanyakan telah menerapkan sistem digital dan online

\section{METODE PELAKSANAAN}

Penelitian pada artikel ini merupakan penelitian kualitatif yang dilakukan dengan menjelaskan dan menganalisis fenomena, peristiwa yang terjadi saat ini atau yang sudah terjadi di masa lampau. dengan tehnik analisis menggunakan kajian kepustakaan (library research). Menurut Sugiyono (2012),mengemukakan bahwa studi kepustakaan merupakan kajian teoritis, referensi serta literatur ilmiah lainnya yang berkaitan dengan budaya, nilai dan norma yang berkembang pada situasi social dari masalah yang menjadi obyek penelitian. Buku-buku, litertur-literatur, catatan-catatan, dan laporan-laporan yang ada hubungannya dengan masalah dalam penelitian di jadikan sebagai dasar dalam menelaah dan menganalisis permasalahan dengan mempelajari dan membacanya lalu data yang di peroleh oleh peneliti di gunakan untuk mengidentifikasi masalah pengaruh tuk memperoleh jawaban dari tujuan penulisan artikel. Dari hasil telaah dan pembahasan me penggunaan google classroom terhadap kualitas dan hasil belajar siswa terhadap mata pelajaran seni musik.Pengaruh hasil belajar dilihat dari respon dan antusias siswa dalam mengikuti pembelajaran. rekapitulasi jumlah absensi siswa dalam kurun waktu 6 bulan pada semester II dari kelas X, bulan Juli sampai dengan Desember 2019. Data tersebut dihimpun oleh kepala sekolah berdasarkan laporan rekap absen setiap akhir bulan. Populasi dan data berikut ini merupakan data awal yang akan dipergunakan sebagai dasar dalam melakukan Perbaikan proses motivasi belajar siswa yang dilakukan kepala sekolah.

Berikut langkah-langkah dalam pelaksanaan kegiatan dari penelitian ini tentang pengaruh penggunaan aplikasi Google Classroom terhadap kualitas pembelajaran dan hasil belajar siswa pada mata pelajaran seni musik di SMA Negeri 1 Candiroto.

1. Perencanaan meliputi kegiatan menentukan tujuan kualitas dan hasil belajar, mengidentifikasi sasaran (siswa) yang akan dijadikan sampel, mengetahui dan menyiapkan sumber-sumber informasi, menyiapkan instrument untuk mengetahui hasil dan kualitas pembelajaran, nenentukan jadwal dan waktu kegiatan dan menetapkan ukuran keberhasilan.

2. Pelaksanaan berisi tentang kegiatan Pengamatan secara langsung, dan penyusunan instrument, Mengenalkan dan menerangkan cara penggunaan google classroom sebagai platform belajar, mengumpulkan data dari instrument yang telah diberikan kepada siswa sasaran, meminimalkan terjadinya kekeliruan atau kesalahan, menjalin kerjasama dengan pihak lain seperti walikelas atau wali murid jika diperlukan.

3. Evaluasi, evaluasi dilakukan untuk mengetahui tingkat keberhasilan belajar dari penggunaan aplikasi google classroom pada mata pelajaran seni musik. Evaluasi yang dlakukan meliputi evaluasi adanya pengaruh penggunaan aplikasi google classroom 
terhadap kualitas pembelajaran mata pelajaran seni music pada siswa kelas $\mathrm{X}$ dan evaluasi adanya pengaruh penggunaan aplikasi google classroom terhadap hasil belajar pada mata pelajaran seni music pada siswa kelas $\mathrm{X}$ telah ada kesesuain antara rencana yang disusun dengan keberhasilan yang hendak dicapai.

4. Tindak lanjut, merupakan kegiatan yang dilaksanakan setelah mengetahui hasil evaluasi hasil belajar dan kualitas pembelajaran terhadap penggunaan aplikasi google classroom. Tindak lanjut dilaksanakan dalam bentuk penguatan (reinforcement), memperbaiki kekurangan dari proses pembelajaran menggunakan google classroom dan lain-lain yang berkaitan dengan penggunaan aplikasi dalam proses pembelajaran. Melakukan Inovasi dalam penggunaan teknologi baru dapat dilakukan untuk melengkapi kegiatan pembelajaran yang telah dilaksanakan.

\section{HASIL DAN PEMBAHASAN}

\section{Hasil}

Artikel ini disusun untuk mendapatkan gambaran tentang Pengaruh Penggunaan Google Classroom berpengaruh terhadap hasil belajar pada mata pelajaran seni musik kelas $\mathrm{X}$ di SMAN 1 Candiroto .Pernyataan-pernyataan yang terkait dengan penggunaan Google Classroom dalam kegiatan pembelajaran antara lain uji validitas, uji validitas angket, uji instrumen tes dan hasil wawancara.Analisis ini dilakukan dengan cara mengkorelasikan masing-masing skor item dengan skor total. Skor total adalah penjumlahan dari keseluruhan item. Item-item pertanyaan yang berkorelasi signifikan dengan skor total menunjukkan itemitem tersebut mampu memberikan dukungan dalam mengungkap apa yang ingin diungkap, dimana setiap nilai yang ada pada setiap butir pertanyaan dikorelasikan dengan total nilai seluruh butir pertanyaan untuk suatu variabel dengan menggunakan rumus korelasi $p r$ Menurut Sugiyono Cara yang Pearson)digunakan adalah dengan analisa item oduct moment". Bivariate Pearson (Korelasi Produk Momen)

Hasil dari uji validitas instrument angket yang diajukan kepada siswa kelas X 3 SMAN 1 Candiroto, dengan jumlah 32 siswa serta 25 angket soal didapat nilai korelasi antara skor item dengan skor total. Nilai ini kemudian kita bandingkan dengan nilai $r$ tabel, $r$ tabel dicari pada signifikansi 0,05 dengan uji 2 sisi dan jumlah data $n=32$, maka didapat $r$ tabel sebesar 0,361. Berikut ini dapat dilihat hasil dari perhitungan validitas untuk keseluruhan butir pernyataan. Untuk menghitung koefisien Korelasi Pearson Product moment, adapun datanya diperoleh seperti pada tabel 1

Tabel 1. Hasil Perhitungan Uji Validitas Instrumen Angket

\begin{tabular}{|c|c|c|c|c|}
\hline Variabel & Soal & R Hitung & $\begin{array}{c}\text { r } \\
\text { Tabel }\end{array}$ & Keterangan \\
\hline \multirow{7}{*}{$\begin{array}{c}\text { Kualitas } \\
\text { Pembelajaran }\end{array}$} & 1 & 0.6009 & 0.361 & Valid \\
\cline { 2 - 5 } & 2 & 0.6378 & 0.361 & Valid \\
\cline { 2 - 5 } & 3 & 0.8582 & 0.361 & Valid \\
\cline { 2 - 5 } & 4 & 0.8582 & 0.361 & Valid \\
\cline { 2 - 5 } & 5 & 0.8582 & 0.361 & Valid \\
\cline { 2 - 5 } & $\mathbf{6}$ & 0.8313 & 0.361 & Valid \\
\cline { 2 - 5 } & 9 & 0.8117 & 0.361 & Valid \\
\cline { 2 - 5 } & 1 & 0.3496 & 0.361 & Valid \\
\cline { 2 - 5 } & 1 & 0.2669 & 0.361 & Tidak Valid \\
\cline { 2 - 5 } & 1 & 0.7697 & 0.361 & Valid \\
\cline { 2 - 5 } & 1 & 0.8521 & 0.361 & Tidak Valid \\
\cline { 2 - 5 } & 1 & 0.9074 & 0.361 & Valid \\
\hline
\end{tabular}


Vol 1. No 4. Oktober 2021 P-ISSN : 2774-8022, e-ISSN : 2774-5791

\begin{tabular}{|c|c|c|c|c|}
\hline & 1 & 0.8399 & 0.361 & Valid \\
\hline & 1 & 0.7681 & 0.361 & Valid \\
\hline & 1 & 0.5266 & 0.361 & Valid \\
\hline \multirow{6}{*}{$\begin{array}{l}\text { Penggunaan } \\
\text { Google } \\
\text { classroom }(\mathrm{X})\end{array}$} & 1 & 0.5411 & 0.361 & Valid \\
\hline & 1 & 0.6058 & 0.361 & Valid \\
\hline & 2 & 0.9212 & 0.361 & Valid \\
\hline & 2 & 0.7855 & 0.361 & Valid \\
\hline & 2 & 0.8417 & 0.361 & Valid \\
\hline & 2 & 0.8955 & 0.361 & Valid \\
\hline $\begin{array}{l}\text { Waktu Belajar } \\
(\mathrm{X} 2)\end{array}$ & $\begin{array}{l}2 \\
4\end{array}$ & 0.9110 & 0.361 & Valid \\
\hline $\begin{array}{l}\text { Kondisi Kelas } \\
\text { (X3) }\end{array}$ & 2 & 0.8083 & 0.361 & Valid \\
\hline
\end{tabular}

Berdasarkan hasil analisis yang didapat dari Tabel 1 diperoleh nilai korelasi 0,361, dapat disimpulkan bahwa butir instrument angket dengan item nomor 9 dan nomor item 11 nilainya kurang dari $\mathrm{r}$ table. Maka dapat disimpulkan bahwa item nomor tersebut tidak berkorelasi signifikan dengan skor total (dinyatakan tidak valid) sehingga harus dikeluarkan atau diperbaiki. Sedangkan pada item-item nomor lainnya lebih dari 0.361 dan dapat disimpulkan bahwa butir nomor instrument angket tersebut valid.

Hasil dari uji validitas instrument tes yang diajukan kepada siswa kelas X di SMAN 1 Candiroto, dengan jumlah 32 siswa serta 25 angket soal didapat nilai korelasi antara skor item dengan skor total. Nilai ini kemudian kita bandingkan dengan nilai $r$ tabel, $r$ tabel dicari pada signifikansi 0,05 dengan uji 2 sisi dan jumlah data $\mathrm{n}=32$, maka didapat $\mathrm{r}$ tabel sebesar 0,361 . Berikut ini dapat dilihat hasil dari perhitungan validitas untuk keseluruhan butir pemyataan. Untuk menghitung koefisien Korelasi Pearson Product moment, adapun datanya diperoleh seperti pada tabel 2

Tabel 2 Hasil Uji Perhitungan Validitas Instrumen Tes

\begin{tabular}{|c|c|c|c|c|}
\hline Variabel & Soal & RHitung & r Tabel & Ketarangan \\
\hline \multirow{14}{*}{ 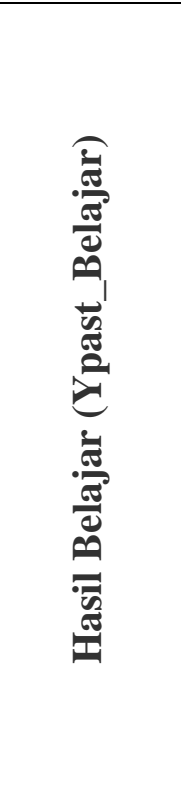 } & 1 & 0.4222 & 0.361 & Valid \\
\hline & 2 & 0.4175 & 0.361 & Valid \\
\hline & 3 & 0.7172 & 0.361 & Valid \\
\hline & 4 & 0.5291 & 0.361 & Valid \\
\hline & 5 & 0.5027 & 0.361 & Valid \\
\hline & 6 & 0.5841 & 0.361 & Valid \\
\hline & 7 & 0.5096 & 0.361 & Valid \\
\hline & 8 & 0.4062 & 0.361 & Valid \\
\hline & 9 & 0.6973 & 0.361 & Valid \\
\hline & 10 & 0.4439 & 0.361 & Valid \\
\hline & 11 & 0.4958 & 0.361 & Valid \\
\hline & 12 & 0.4439 & 0.361 & Valid \\
\hline & 13 & 0.4897 & 0.361 & Valid \\
\hline & 14 & 0.3206 & 0.361 & Tidak Valid \\
\hline
\end{tabular}


SECONDARY : Jurnal Inovasi Pendidikan Menengah

Vol 1. No 4. Oktober 2021 P-ISSN : 2774-8022, e-ISSN : 2774-5791

\begin{tabular}{|c|c|c|c|c|}
\hline 15 & 0.4981 & 0.361 & Valid \\
\cline { 2 - 5 } & 16 & 0.4135 & 0.361 & Valid \\
\cline { 2 - 5 } & 17 & 0.4468 & 0.361 & Valid \\
\cline { 2 - 5 } & 18 & 0.4574 & 0.361 & Valid \\
\cline { 2 - 5 } & 19 & 0.7541 & 0.361 & Valid \\
\cline { 2 - 5 } & 20 & 0.5013 & 0.361 & Valid \\
\cline { 2 - 5 } & 21 & 0.6625 & 0.361 & Valid \\
\cline { 2 - 5 } & 22 & 0.0329 & 0.361 & Tidak Valid \\
\cline { 2 - 5 } & 23 & 0.5738 & 0.361 & Valid \\
\cline { 2 - 5 } & 24 & 0.4354 & 0.361 & Valid \\
\cline { 2 - 5 } & 25 & 0.5683 & 0.361 & Valid \\
\hline
\end{tabular}

Berdasarkan hasil analisis yang didapat dari Tabel 2 diperoleh nilai korelasi 0,361, dapat disimpulkan bahwa butir instrument tes dengan item nomor 14 dan item nomor 22 nilainya kurang dari $r$ table. Maka dapat disimpulkan bahwa dua item nomor tersebut tidak berkorelasi signifikan dengan skor total (dinyatakan tidak valid) sehingga harus dikeluarkan atau diperbaiki. Sedangkan pada item-item nomor lainnya lebih dari 0.361 dan dapat disimpulkan bahwa butir nomor instrument angket tersebut valid.

\section{Pembahasan}

Peneliti telah melakukan wawancara kepada guru mata pelajaran seni musik dan dua siswa kelas X 3. Wawancara ini dilakukan setelah penyebaran angket kepada siswa kelas X di SMAN 1 Candiroto pada 21 Mei 2020. Berikut hasil wawancara dengan guru mata pelajaran seni musik yaitu bapak Achmad Solichul Hadi, S.Pd dan hasil wawancara dengan dua siswa kelas X 3 yaitu Zakaria Hary Septiawan dan Rizka Mandasari.

Berdasarkan hasil wawancara dengan guru mata pelajaran seni music menjelaskan bahwa kegiatan belajar mengajar yang dilakukan oleh guru mata pelajaran seni musik ada di SMAN 1 Candiroto ini telah menggunakan berbagai media, baik itu media yang sederhana maupun media yang berkaitan dengan tekologi pembelajaran. Penggunaan media tersebut bertujuan untuk memudahkan siswa dalam memahami materi pelajaran yang disampaikan oleh guru. Penggunaan media pembelajaran yang dilakukan guru seni music dalam proses kegiatan belajar mengajar sudah digunakan dengan baik. Guru telah menggunakan berbagai media pembelajaran seperti, power point, internet, dan juga Google Classroom Kesimpulan dari wawancara ini bahwa penggunaan Google Classroom dalam kegiatan pembelajaran memberikan kemudahan siswa dalam memahami pelajaran, pembelajaran menjadi lebih efekif dan efisien, dan memberikan hasil belajar yang baik bagi siswa.

Berdasarkan hasil pencarian studi literatur didapatkan Jurnal Penelitian yang relevan dengan penelitian yang saya lakukan. Yaitu oleh Abdul Barir Hakim (2016), dengan judul Efektifitas Penggunaan E-Learning Moodle Google Classroom Dan Edmodo pada jurnal ISTATEMENT Vol. 02 No 1, STIMIK ESQ, Jakarta, dengan hasil bahwa Moodle mempunyai fitur yang lengkap administrator dalam penggunaannya. Edmodo dan Google Classroom adalah layanan berbasis Internet, sehingga tidak memerlukan hosting di server sendiri. Adapun persamaan penelitian ini dengan artikel Best Practice saya adalah mencari pengaruh penggunaan Google classroom dalam kegiatan pembelajaran, Perbedaan penelitian ini dengan artikel Best practice yang saya lakukan adalah Pengumpulan data: interview. lokasi penelitianya di STIMIK ESQ Jakarta. 


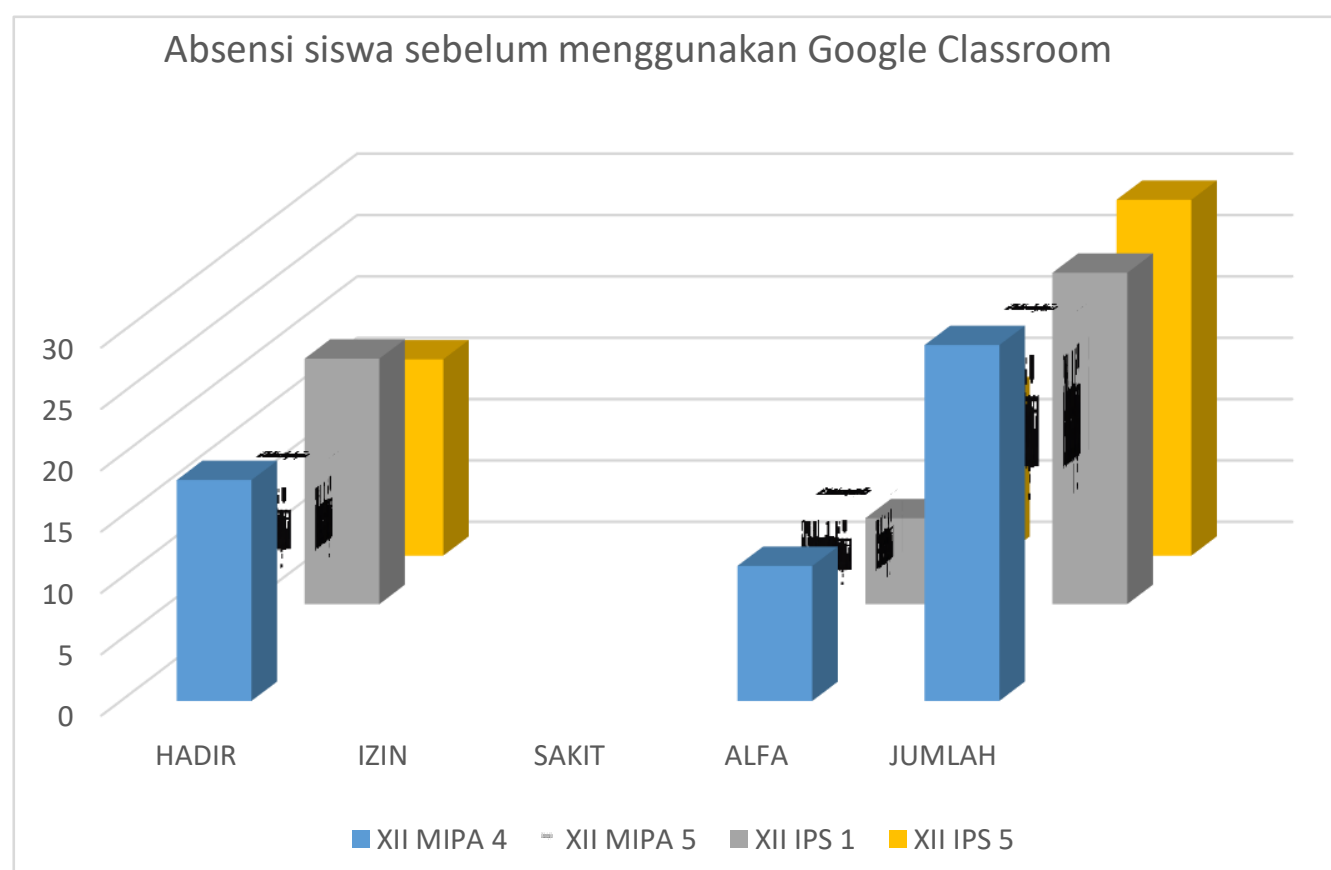

Gambar 1. Grafik Absensi kehadiran siswa sebelum menggunakan Google Classroom

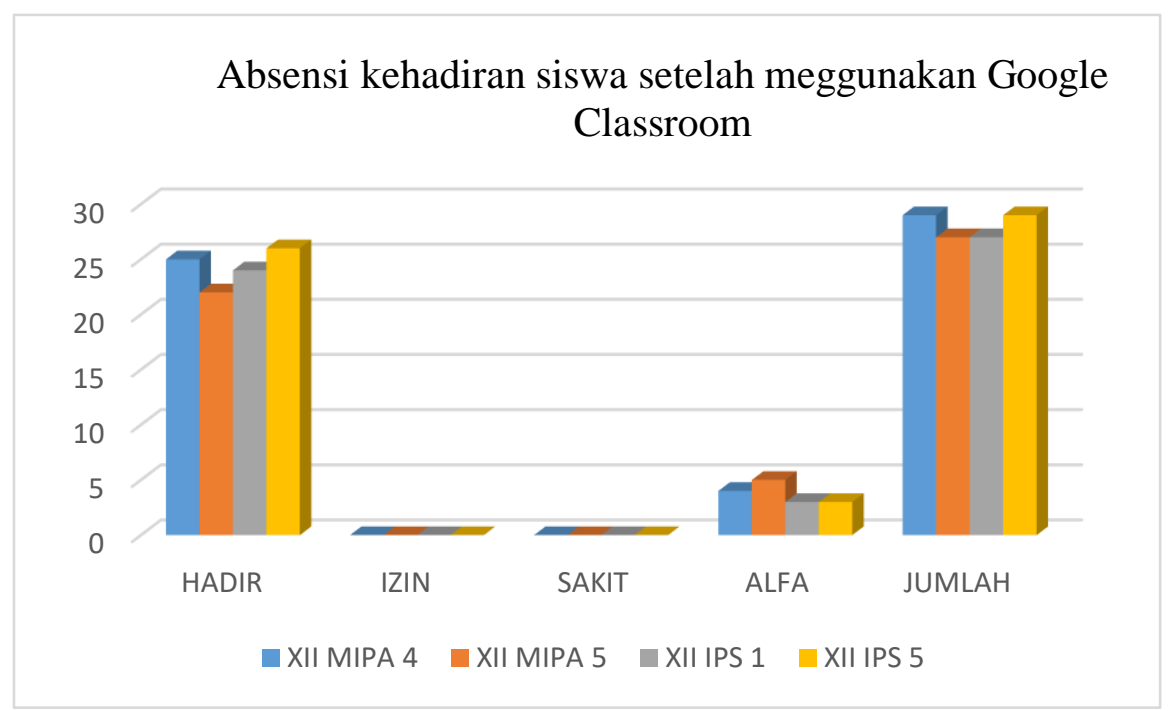

Gambar 2. Grafik Absensi kehadiran siswa setelah menggunakan Google Classroom

Grafik 2 menunjukkan kehadiran siswa sebelum menggunakan Google Classroom mencapai $61.61 \%$, sedangan kehadiran siswa setelah mengggunakan Google Classroom sebesar $83.92 \%$ yang ditunjukkan pada grafik 2 Perbedaaan angka dari hasil grafik 1. dan 2 Terlihat signifikan perbedaannya $22,31 \%$ kehadiran siswa yang menggunakan pengembangan Google Classroom lebih besar

Penggunaan Google Classroom waktu belajar, dan kondisi belajar memiliki pengaruh cukup besar terhadap hasil belajar. Nilai koefisien regresi bersama-sama menunjukan terdapat pengaruh signifikan secara bersama-sama antara variabel Penggunaan Google Classroom, waktu belajar, dan kondisi belajar berpengaruh terhadap hasil belajar. Hasil penelitian ini sesuai dengan penelitian dari Diemas Bagas Panca dan Rina Harimurti (2017) berjudul "Pengaruh Penggunaan Tools Google Classroom Pada Model Pembelajaran Project Based Leaming Terhadap Hasil Belajar Siswa". Penelitian ini menunjukan terdapat perbedaan hasil belajar yang signifikan antara kelas eksperimen yang menggunakan pembelajaran berbasis 
proyek digabungkan dengan Google Classroom dan kelas kontrol yang hanya menggunakan pembelajaran berbasis proyek. Hasil belajar siswa dengan penggunaan Tools Google Classroom pada model pembelajaran Project Based Leaming lebih tinggi dibandingkan dengan hasil belajar siswa pada model pembelajaran Project Based Learning tanpa menggunakan Tools Google Classroom. Sesuai juga dengan penelitian Siti Shofiah (2016) berjudul "Pengaruh Penggunaan Android dan E-learning Terhadap Hasil belajar Mata Pelajaran IPS Kelas VIII SMPN 3 Kepanjen Malang". Penelitian ini menunjukan terdapat pengaruh positif signifikan penggunaan Android terhadap hasil belajar dengan nilai thitung $>$ t tabel (3.204> 2.01) dengan nilai signifikansi 0.002. Artinya penggunaan Android sebagai sumber belajar dan media belajar dapat meningkatkan hasil belajar siswa.

Hasil analisis data di atas mengindikasikan bahwa penggunaan Google Classroom berpengaruh terhadap hasil belajar siswa Semakin baik penggunaan Google Classroom maka hasil belajar siswa akan ikut meningkat. Sedangkan waktu belajar berpengaruh 0.202 kali dan kondisi kelas 6.606 kali terhadap hasil belajar. Kedua variabel tersebut memiliki pengaruh tetapi tidak mempengaruhi secara signifikan. Hal ini sesuai dengan penelitian dari Dina Kurnianingtyas (2016) yang berjudul "pengaruh pemanfaatan waktu belajar siswa di luar jam pelajaran dan perhatian orang tua terhadap prestasi belajar akuntansi siswa kelas XI IPS SMAN 2 Sleman" penelitian ini menunjukan pengaruh positif pemanfaatan waktu belajar siswa di luar jam pelajaran terhadap prestasi belajar seni musik siswa kelas X 3 SMAN 1 Candiroto dengan nilai $t$ hitung $>t$ tabel $(3.621>2.005)$. Sesuai juga dengan penelitian dari Ria Aini (2014) yang berjudul pengaruh pengelolaan kelas terhadap hasil belajar siswa pada mata pelajaran seni music kelas X 2 di SMAN 8 Pontianak. Penelitian ini menunjukan terdapat pengaruh signifikan manajemen kelas terhadap hasil belajar siswa di SMAN 8 Pontianak Ogan Komering Ilir dengan nilai t hitung $>t$ tabel $(5.192>2.003)$.

Hasil analisis data di atas mengindikasikan bahwa waktu belajar dan kondisi kelas berpengaruh terhadap hasil belajar siswa tetapi tidak signifikan. Semakin baik penggunaan waktu belajar dan kondisi kelas maka hasil belajar siswa akan ikut meningkat.Hasil pengujian hipotesis secara parsial menggunakan parameter Wald menunjukan bahwa penggunaan Google Classroom berpengaruh 2,44 kali terhadap hasil belajar secara signifikan. Berdasarkan hal tersebut menyatakan Penggunaan Google Classroom berpengaruh terhadap hasil belajar pada mata pelajaran seni musik kelas X di SMAN 1 Candiroto.

\section{RESPON PESERTA DIDIK TERHADAP PENGGUNAAN APLIKASI GOOGLE CLASSROOM}

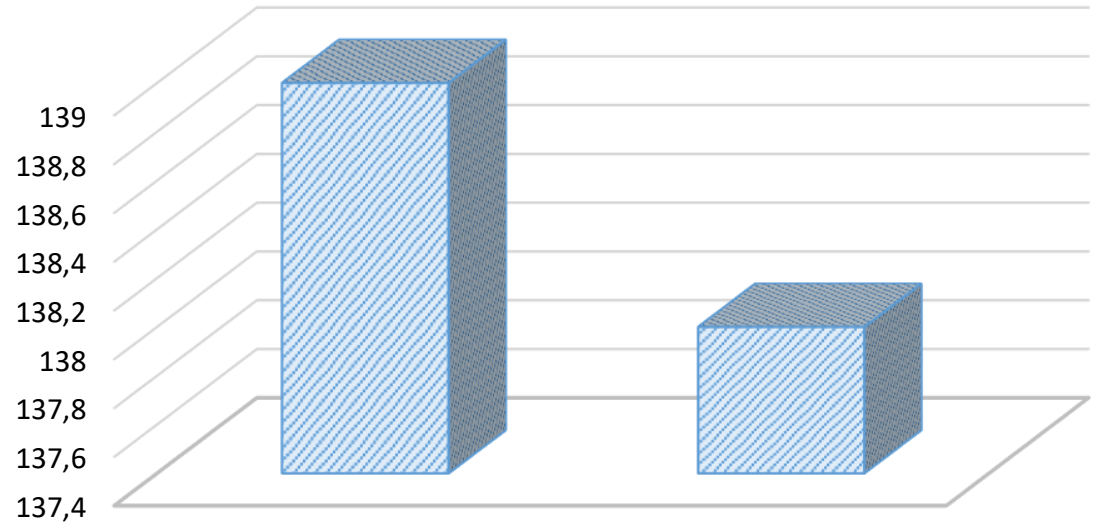

\section{Gambar 3. Grafik Respon peserta didik terhadap penggunaan Google Classroom}

Masalah lain yang dihadapi adalah banyak guru yang tidak mempunyai kemampuan untuk membuat menggunakan Google Classroom dan memanfaatkan berbagai fasilitas didalamnya, padahal Google Classroom merupakan media pembelajaran yang mudah dan 
mendukung pada saat pembelajaran jarak jauh. Serta memberikan pemahaman dan kesadaran akan pentingnya pembelajaran meskipun dengan jarak jauh, sehingga target pencapaian nilai anak-anak tercapai sesuai dengan KKM yang telah ditetapkan. Disadari bahwa terdapat banyak faktor yang mempengaruhi kualitas pembelajaran dan hasil belajar siswa pada mata pelajaran seni musik, sementara ini peneliti hanya melibatkan tiga variabel saja yaitu penggunaan Google Classroom sebagai variabel utama, waktu belajar dan kondisi belajar sebagai variabel kontrol dalam meningkatkan kualitas pembelajaran dan hasil belajar siswa. Variabel waktu belajar dan kondisi kelas dalam penelitian ini tidak berpengaruh secara signifikan karena hanya rnenggunakan satu indikator saja dari masing-rnasing variabel. Variabel waktu belajar hanya diukur pada waktu belajar yang kurang dari satu jam selama di rumah. Sedangkan variabel kondisi kelas yang kurang kondusif karena pernbelajaran terjadi pada siang hari.

\section{KESIMPULAN}

Penggunaan google classroom berpengaruh positif terhadap hasil belajar siswa pada mata pelajaran seni musik kelas $\mathrm{X}$ di SMAN 1 Candiroto Hal ini ditunjukan menggunakan regresi logisik ordinal diperoleh nilai $R$ (Nagelkerke) sebesar 0.746 , dan nilai estimate sebesar 0.892 yang dieksponensialkan menjadi 2.44 dengan signifikansi $0.016<0.05$. dengan demikian semakin baik penggunaan google classroom maka akan semakin baik kualitas pembelajaran yang ada di kelas dan semakin baik pula hasil belajar siswa pada mata pelajaran seni musik kelas X di SMAN 1 Candiroto

\section{DAFTAR PUSTAKA}

Aini, R. (2014). Pengaruh Pengelolaan Kelas Terhadap Hasil Belajar Siswa Pada Mata Pelajaran Ekonomi Kelas X IPS di SMAN 8 Pontianak: Artikel penelitian Universitas Tanjungpura Pontianak.

Arikunto, Suharsimi (2013) Prosedur Penelitian: Suatu Pendekatan Praktik. Jakarta: Rineka Cipta.

Atikah, R., Prihatin, R,.A., Hernayati, H. \& Misbah, J. (2021). Pemanfaatan Google Classroom Sebagai Media Pembelajaran Di Masa Pandemi Covid-19. Jurnal Petik, Volume 7, No1, Hal 7 .

Basilaia, G, \& Kvavadze, D. (2020). Transition to Online Education in Schools during SARSCoV-2 Coronavirus (COVID-19) Pandemic in Georgia. Pedagogical Research, 5 (4). https://doi.org/10.29333/pr/7937

Dicky Pratama dan Hendri Sopryadi, (2016). Pengaruh Pemanfaatan Kelas Elektronik TerhadapEfektifitas dan Efisiensi Proses Belajar STMIK XYZ, Jurnal Jatisi, Vol. 03 No. 1, STMIK GI MDP, Palembang.

Djamarah, Syaiful B. (2006). dan Aswan Zain. Strategi Belajar Mengajar. Jakarta: PT Rineka Cipta.

Hakim, Abdul Barir. (2006). Efektifitas Penggunaan E-Learning Moodle, Google Classroom Dan Edmodo: Jurnal I-Statement Vol. 02 No 1.

Hardiyana, Andri, (2015). Implementasi Google Classroom Sebagai Alternatif Dalam Meningkatkan Mutu Pembelajaran Di Sekolah. Karya Tulis Ilmiah (LKTI) Tingkat Nasional. SMAN 1 Losari Dinas Pendidikan Kabupaten Cirebon Provinsi Jawa Barat.

Gunawan., Yeni Suranti,N.M., Fathoroni. (2020).Variations of Models and Learning Platforms for Prospective Teachers During the COVID -19 Pandemic Period. Indonesian Journal of Teacher Education, Vol. 1 No. 2, 2020: 61-70

Ghozali, Imam. (2013). Aplikasi Analisis Multivariate dengan Program IBM SPSS 23.Semarang: Badan Penerbit-Undip.

Irham, Muhammad dan Novan Ardy W. 2016. Psikologi Pendidikan-Teori dan Aplikasi dalam Proses Pembelajaran. Yogyakarta: Ar-Ruzz Media.

Kriyantono, Rachmat. (2006). Teknik Praktis Riset Komunikasi. Jakarta: Kencana. 
Syahrin, Siti Alfi. (2015). "Pengaruh Model Pembelajaran Blanded Learning Terhadap Hasil Belajar Mata Pelajaran IPS Siswa Kelas 8 Di SMPN 37 Jakarta". Skripsi pada Universitas Islam Negeri Syarif Hidayatullah Jakarta.

Rusman. (2013). Belajar dan Pembelajaran Berbasis Komputer Mengembangkan Profesionalisme Guru Abad 21. Bandung: Alfabeta.

Rusman, dkk, (2015). Pembelajaran Berbasis Teknologi Informasi dan Komunikasi: Mengembangkan Profsionalisme Guru. Jakarta: PT Raja Grafindo Persada.

Sanjaya, W. (2009). Penelitian Tindakan Kelas. Jakarta: Kencana.

Siregar, S (2013). Statistik Parametrik untuk Penelitian Kuantitatif. Jakarta: Bumi Aksara.

Slameto. (2013). Belajar dan Faktor-Faktor yang Mempengaruhinya. Jakarta: Rineka Cipta.

Suartama, I Kadek dan I Dewa Kade Tastra, (2013). E-learning Berbasis Moodie. Yogyakarta: Grahala Ilmu.

Sugiyono, (2015). Metode Penelitian Pendidikan Pendekatan Kuantitatif, kualitatif, dan $R$ $\& D$. Bandung: Alfabeta.

Sukmadinata, (2011). Nana Syaodih. LAndasan Psikologi Proses Pendidikan. Bandung: PT Remaja Rosdakarya.

Suprihatiningsih, (2016). Perspektif Manajemen Pembelajaran Program Keterampilan. Yogyakarta: Deepublish. 